\title{
What Can Central Banks Do About the Value of the Dollar?
}

\author{
Dallas S. Batten and Mack Ott
}

VER the past four years, the stubborn strength of the U.S. dollar in foreign currency markets has created what many observers believe is a precarious balance between two undesirable features of the floating exchange rate system. On the one hand, some argue that the dollar is overvalued and, consequently, soon will fall dramatically, generating increased U.S. inflation and jeopardizing world financial stability. On the other hand, others argue that the "high" dollar was a major cause of the 1981-82 economic recession and now assert that the current expansion is not sustainable without a substantial decline in the foreign exchange value of the dollar. ${ }^{1}$

Surprisingly, both sets of dollar critics have advanced the same policy prescription: intervene in foreign exchange markets. In other words, the monetary

Dallas S. Batten and Mack Ott are senior economists at the Federal Reserve Bank of Sf. Louis. Paul G. Christopher provided research assistance.

${ }^{1}$ For examples, consider Kraus (1984), Arenson (1984) and Bank for International Settlements (1984). In the last (p. 1), Dr. Gleske, a member of the Directorate of the Deutsche Bundesbank, was somewhat bemused by the dollar's persistent high value:

There sherefore seem to be enough reasons to support expectations that the dollar rate will cocline. However, contrary to all historical experiance, these expectations have not been fulfilled as yet. The markets do not seem to have any expectations of this nature, either. Apparently. investing in dollar assets - especially in the United States itself continues to be lucrative despite the creater exchange rate risk, and the markets appear up to now to have hardly any doubts that the dollar will remain attractive despite the fact that the fundamental factors like the declining competitiveness of U.S. industry and sharply rising currentaccount deficits operate father in favour of expecting the opposite. authorities of the United States and its major trading partners should buy and sell foreign currencies. "The first set of critics urges this policy to manage the fall of the dollar's foreign exchange value, while the second urges it to bring down the value of the dollar in order to stimulate the U.S. traded goods sectors.2

'The purpose of this paper is to explain the fundamentals of central bank intervention in foreign exchange markets and the conditions required for it to be effective. First, the motives, mechanics and consequences of intervention are discussed. Next, the relationship between intervention and domestic monetary policy is investigated. Finally, some qualitative and quantitative evidence on the efficacy of intervention is reviewed.

\section{WHY CEITITAL BANKS INTERVENE}

The exchange rate is the price of one country's currency in terms of another. As the relative price of two assets (currencies), it is determined by the forces of demand and supply, as are the prices of other assets,

\footnotetext{
${ }^{2}$ Traded goods are those goods that are potentially exportable or importable - - whether or not they are actually consumed domestically or abroad. For instance, agricultura commodities, airplanes and steel are traded goods, while haircuts, legal services and housing are primarily nontraded goods. The importance of the distinction between traded and nontraded goods is that changes in toreign competition will directly affect production and sales both in the home and foreign markets in the traded goods sector, while only indirectly affecting production and sales in the nontraded goods sector.
} 
such as stocks, bonds or real estate. ${ }^{3}$ Moreover, the relative valuations of and yields on non-currency assets also have, as we shall see, large impacts on the exchange rate.

Unlike the prices of services or nondurable goods, asset prices reflect primarily the market's expectations about future economic conditions. Consequently, in the short run, exchange rates should be influenced predominantly by new information - that is, surprises - which alters expectations of future events; these surprises lead to highly unpredictable and often sizable movements in exchange rates. Because news can be incorrect and because markets can overreact to news even when it is comect, monetary authorities typically believe that much of the short-run volatility exhibited by foreign exchange markets is excessive. Consequently, intervention is frequently rationalized by central banks as a means to reduce the presumed excessive variability of exchange rate movements resulting from the variability of market expectations. ${ }^{5}$

In the long run, movements of exchange rates tend toward a relationship among currencies known as pur chasing power parity (PPP). That is, a dollar or yen or deutsche mark (DM) would each purchase the same amount of goods whether expended at home or abroad. Thus, a country with a relatively rapid inflation rate will have its currency decline in value relative to the currencies of countries with slower inflation rates.

Ignoring long-run considerations, frequent and offsetting exchange rate movements in the short or

\footnotetext{
3Policymakers sometimes argue that it is 100 important to be deter mined solely by market forces. Consider, for example, the view of Dr. Otmar Emminger, former President of the Deutsche Bundesbank, as expressed in a speech to a Bankers' Forum at Georgetown University, Washington, D.C., on September 28, 1981 (see Bank for Interna* tional Settlements [1982], p. 4):
}

The exchange rate is far too important a price - because of its effects on domestic stabitity and activity, the balance of payments, and international trade and payments relations - - to be tyeated with bentgn neglect" as a 'residual outcome' of domestic monetary and other economic poticies. This should not be mistinderstood as a call for activism and interventionism in the field of exchange rates. If cannot be emphasised too much that the most important foundation for excharge rate stability is a policy of monetary and financial stablity at home. We would, however, delude ourselves if we believed that al that is required for stable exchange rates is the pursuit of a steady money supply poilcy. Short and meditum-term stains and disturbances are builtin elements in the fietd of payments and exchange markess, even if we had firm international agreement and successful implementation of concerted money supply policies.

4This concern, however, appears to be misdirected as Bergstrand (1983) has demonstrated that exchange rates are actually less variable than other asset prices.

5 For additional support for this characterization, see Kubarych (1983), pp. $6-19$ and $43-45$. intermediate term can be more than just a nuisance to monetary authorities - they also can have real effects. For example, an appreciation of the exchange rate beyond that necessary to offset the inflation differential between two countries (termed "overshooting") raises the price of traded goods in the home country relative to the prices of traded goods in the rest of the world. Thus, home country exports become less competitive in world markets and home country import substitutes less competitive in domestic markets. Consequently, sales of traded goods decline, generating unemploy ment in the traded goods sector and, subsequently, inducing a shift of resources from the traded to the nontraded goods sector.

This reallocation of resources is efficient for the economy if that portion of the exchange rate appreciation in excess of the inflation differential is permanent. If this excess portion of the exchange rate appreciation is short-lived (i.e., reversed in the near future), the corresponding movement of resources will be reversed, and the economy will have experienced un* necessary unemployment due to the costs of shifting resources, reallocating capital, laying off and hiring. Monetary authorities who wish to avoid such situam tions may intervene to oppose exchange rate movements that they believe will not persist. This is a feasible policy, however, only if they can distinguish temporary exchange rate fluctuations from permanent ones. $^{6}$

Exchange rate changes also affect the general price level and may generate some measured short-run inflation or disinflation as markets adjust to the changing relative price of traded to nontraded goods. In particular, an exchange rate depreciation raises the domestic currency price of imports and, thus, raises the domestic price level. Because the total impact of this change is not felt all at once, the price level continues to rise for some time. 'Thus, since exchange rate depreciation usually precedes changes in domestic prices, it may appear to cause inflation.?

\footnotetext{
${ }^{6}$ This distinction is difficult to rake in practice. As Martin Feldstein (1983), p. 48, observed:

[There is no way in practice to distinguish an exchange-rate movement that is merely a random fluctuation from one that is part of a fundamertal shif: in the equifibrim exchange rate. Exchange-market intervention aimed at smoothing a fransitory disturbance may in fact be a counterproductive or futile attempt to prevent a basic shift in the equilibrium exchange rate.
}

Furthermore, this overshooting may occur because asset markets clear more rapidy than do goods markets, and, as a result, it may not be undesirable.

7For a more detaijed discussion of the relationship between domestic inftation and exchange rate changes, see Batten and Ott (1983). 


\section{Figure 1}

\section{U.S. Intervention to Support the Deutsche Mark}

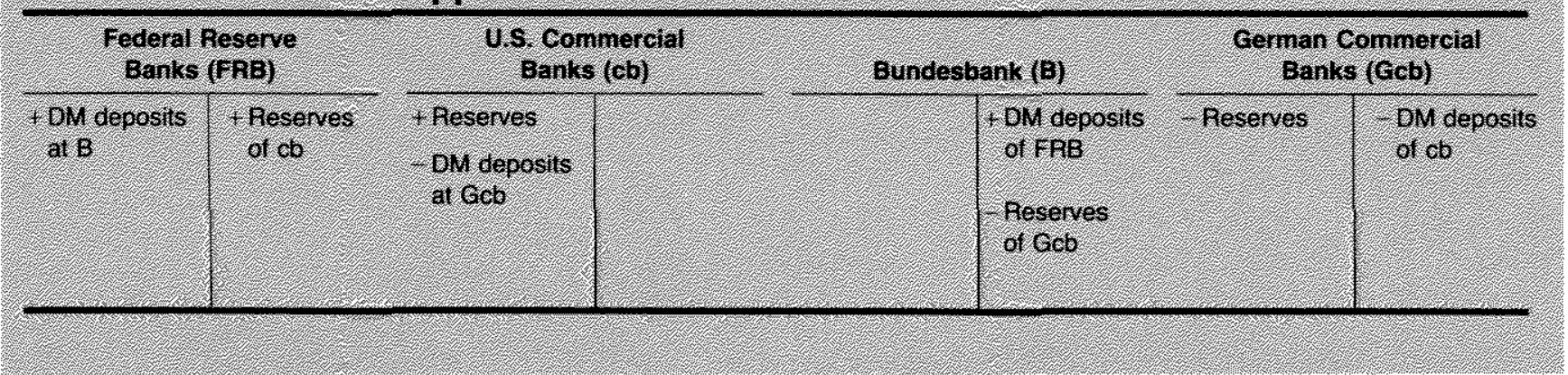

Finally, many domestic residents, firms and, especially $y_{f}$ multinational corporations have financial assets and liabilities denominated in foreign currencies. Exchange rate changes, then, produce wealth effects since they generate capital losses and gains. For example, if the U.S. exchange rate unexpectedly appreciates, the dollar values of foreign-currency-denominated assets and liabilities fall. Hence, U.S. net monetary debtors in foreign currencies experience gains, and net creditors experience losses. ${ }^{8}$

In sum, changes in exchange rates have consequences that monetary authorities may deem undesirable. Thus, having chosen not to allow exchange rates to be completely market-determined, many central banks intervene periodically in foreign exchange markets to mitigate what they believe to be transient but deleterious effects of exchange rate movements on the domestic economy.

\section{HOW CENTRAL BANKS INTERVENE}

The mechanics of central bank intervention in foreign exchange markets can take a variety of forms. The general purpose of each variant, however, is basically the same: augment the market demand for one currency by augmenting the market supply of another. An exhaustive explanation of the ways in which intervention can be conducted is beyond the scope of this paper. ${ }^{9}$ Instead, we will describe the most frequently

\footnotetext{
${ }^{8} \mathrm{~A}$ net monetary foreign currency debtor is an individual or firm with greater monetary debts than monetary claims in a foreign currency. Thus, when that foreign currency depreciates, his foreign liabilities decline in value more than his foreign assets, and, on net, his wealth rises. Similarly, a foreign currency depreciation would lower the wealth of a net monetary foreign currency creditor.

${ }^{9}$ See Babach (1978) for a detalled analysis of various forms of intervention.
}

employed method - intervention by the monetary authority.

\section{A Typical Example}

Suppose that the dollar is believed to be overvalued. The Federal Reserve Bank of New York, which acts as the agent for U.S. foreign exchange market interventions, will purchase foreign currency, typically DM, with U.S. dollars. ${ }^{10}$ It can do this simply by creating dollar reserves and using them to purchase DM. In particular, the Fed can purchase DM-denominated deposits of U.S. banks at German banks and pay for them by crediting the reserve accounts of these U.S. banks. The Fed then presents to the Bundesbank drafts drawn against accounts of these U.S. banks at German banks, which are subsequently cleared by the Bundesbank. The impact of this transaction on the financial institutions involved is outlined in figure 1 . In general, the reserves of the U.S. banking system increase, while those of the German banking system fall. The changes in the reserve positions of the United States and Germany that result from this foreign exchange operation will cause the U.S. money stock to rise and Germany's money stock to fall.

Conversely, if the Bundesbank believes the DM to be undervalued (i.e., the dollar is overvalued), it could reduce the quantity of $\mathrm{DM}$ relative to dollars. This transaction is slightly more complicated than when the Fed intervenes in support of the DM. First, the Bundesbank must acquite dollars. It typically does this either by selling some of its non-negotiable U.S. Treasury securities to the Fed or by borrowing from the

\footnotetext{
10 In the United States, the Federal Reserve Bank of New York inter. venes for the Federal Reserve System and the U.S. Treasury. The decision to intervene, however, is made by the U.S. Treasury.
} 


\section{Figure 2}

\section{German Intervention to Support the Deutsche Mark}

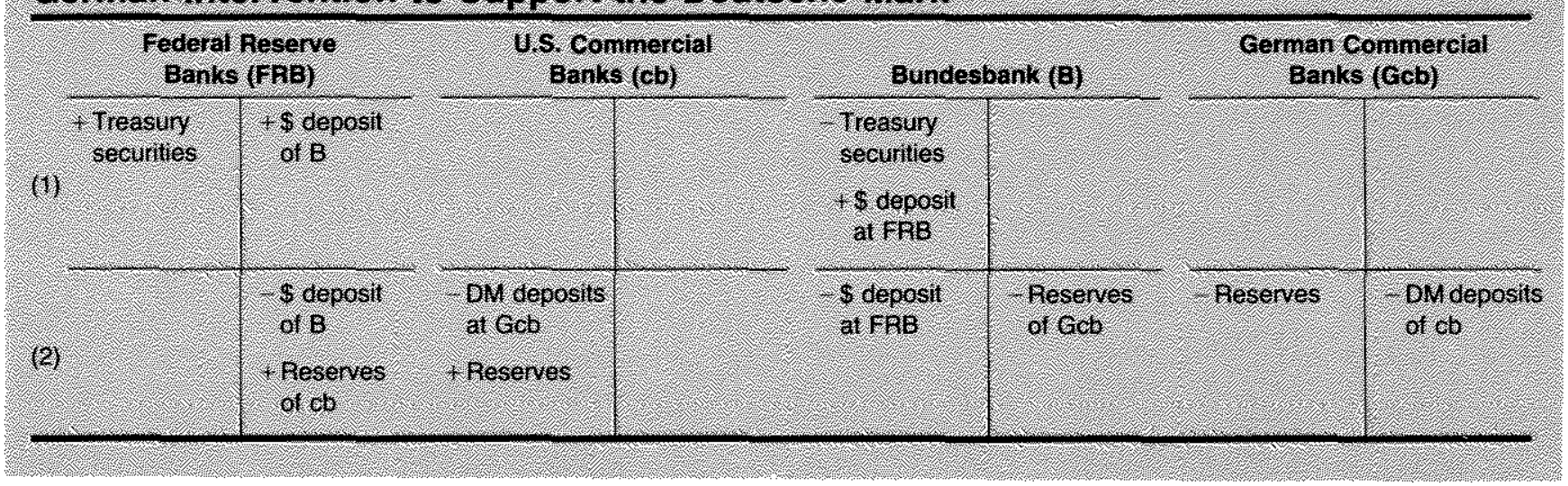

Fed in exchange for a dollar-denominated account through a swap arrangement already established between the two. These acquired dollars are then used to buy DM in the foreign exchange market.

In figure 2 , step 1 depicts the acquisition by the Bundesbank of a dollar-denominated deposit at the Fed. Since this transaction is between central banks, it does not affect the reserves of the banking system in either country and, hence, does not affect either country's domestic money supply. In step 2, the Bundesbank purchases DM-denominated deposits of U.S. commercial banks held at German commercial banks with dollars. This transaction is cleared by U.S. banks presenting to the Fed dollar-denominated claims against the Bundesbank and receiving reserves in return. (At the same time, the Fed reduces its deposit liabilities to the Bundesbank.) Likewise, the Bundesbank clears the draft it purchased from U.S. banks by lowering its reserve liabilities to German banks. And finally, German banks, presented with a draft against deposits of U.S. banks, reduce their deposit liabilities to these banks by the amount of the reduction in their reserve deposits at the Bundesbank. The final result is the same as in the preceding case - the reserves of the U.S. banking system rise, while those in the German banking system fall.

\section{Sterihzed vs. Unstervized Intervention}

The two examples discussed above are instances of unsterilized intervention; that is, the domestic money supplies have not been insulated from the foreign exchange market transaction. If unsterilized intervention is undertaken in large amounts, it will affect not only the money supplies of both countries, but domestic prices and interest rates as well. If monetary author- ities do not want their foreign exchange market intervention to affect their domestic economies, they may sterilize its impact with an offsetting sale or purchase of domestic assets.

Sterilized intervention would be the preferred procedure if the Fed did not want the U.S. banking system's reserves to change. Thus, if the unsterilized intervention interfered with the goals of domestic monetary policy, the Fed could sell U.S. Treasury securities in U.S. financial markets equal to the amount of reserves created by the intervention. With this transaction, the level of reserves in the U.S. banking system would return to its preintervention level, and, as a result, there would be no subsequent change in the U.S. money supply.

Similarly, the Bundesbank could neutralize the impact of intervention on the German money supply by injecting new reserves into its banking system. If sterilized completely, the foreign exchange operation would not affect either country's money supply. Thus, in the case of a completely sterilized intervention, private portfolios would contain fewer DMdenominated securities and more dollar-denominated securities, while the Fed's portfolio would contain more DM-denominated securities and fewer dollardenominated ones.

\section{THE EXCHANGE TRATE CONSEOUENCES OF CENTRAL BANK INTERVERTTON}

Exchange rate movements reflect two fundamental characteristics that must be recognized to understand the impact of intervention. First, changes in exchange rates, like changes in the price of any asset, are highly 
irregular and umpredictable in the short run, reflecting primarily new events that alter the market's expectations of future exchange rate movements. Second, since the exchange rate is the relative price of two currencies, its movements reflect changes in policies that affect either the supplies of these currencies or the demands to hold them. More specifically, exchange rates reflect anticipated relative inflation rates that are generated by both past and expected future policy actions of the countries involved. Therefore, currencies of countries with lower expected inflation rates are cheaper to hold and are in greater demand than those of countries with higher inflation rates, all other things equal. Consequently, it follows from PPP that currencies of higher-inflation countries tend to depreciate relative to those of lower-inflation countries.

The different impacts of sterilized and unsterilized intervention on the exchange rate can be analyzed in terms of these two characteristics. Suppose, as outlined above, that either the Fed or the Bundesbank purchases DM with U.S. dollars. This transaction increases the short-run flow demand for DM relative to the supply of DM and should result in an appreciation of the DM, all other things equal. This impact will be only transitory, however, unless the central bank continues to purchase DM day after day, thereby maintaining the higher flow demand for DM.

More importantly, since this transaction is unsterilized, it causes the U.S. money supply to rise and the Geman money supply to fall. If large enough, this intervention has two potential effects: a transient effect on the current markets for the two currencies and a permanent effect on expected future relative inflation rates. Other things equal, the resulting excess supply of U.S. money in the United States and excess demand for German money in Germany will cause the two countries' money markets to clear at lower and higher rates of interest, respectively. This immediate, but transitory, effect will cause the dollar to decline relative to the DM as German assets temporarily have higher yields than U.S. assets.

Whether this effect on the exchange rate is lasting or transient, however, depends crucially on the expectations of investors holding U.S. and German assets. If these expectations are unchanged, individuats holding U.S. assets would sell them - driving up their yields and buy German assets - depressing their yields thereby tending to offset the central bank's actions. That is, just as a single private individual in a competitive market can have no effect on asset prices by his sales or purchases, so even central banks will not affect assef prices unless their activity is substantial or their actions affect market expectations.

This intervention may affect market expectations about relative asset yields and prices if market participants interpret the expansion of the U.S. money supply as an indicator of a permanent increase in the rate of monetary growth planned by the Fed. Such expectam tions of further easing of U.S. monetary policy will cause market participants to anticipate increases in the rate of U.S. inflation relative to German inflation. These expectations of relatively higher future U.S. inflam tion will decrease the desire of foreigners to hold dollars since they expect the dollar's purchasing power to continue to fall. Consequently, the DM value of the dollar will depreciate at a rate equal to the difference between the now higher anticipated rate of inflation in the United States and that in Germany. ${ }^{11}$

If the intervention is sterilized, its immediate impact is the same as that for unsterilized intervention; that is, if generates a temporary increase in the flow demand for DM. The net effect of this sterilized intervention is simply that private portfolios will contain more dollardenominated and fewer DM-denominated securities; neither country's money supply will be affected. Consequently, it is not clear what lasting impact this type of intervention will have on the DM/dollar exchange rate.

Because sterilized intervention entails a substitution of dollar-denominated securities for DM-denominated ones, however, the exchange rate will be permanently affected only if the investors view domestic and foreign securities as being imperfect substitutes. If this is the case, investors will be unwilling to hold the new portfollo at unchanged exchange and interest rates. In fact, at the original exchange and interest rates, an excess demand for DM-denominated securities will arise. Consequently, investors will attempt to acquire additional DM-denominated securities in order to return their portfolios to the desired proportion of dollardenominated securities, thereby placing downward pressure on the DM value of the dollar.

If investors consider these securities to be perfect substitutes, on the other hand, no change in either the

\footnotetext{
${ }^{11}$ This discussion is oversimplified in that it isolates ony two currencies and the exchange rate between them. In the real world, there are numerous currencies and exchange rates. Attempts to affect the exchange rate between any pair of currencies necessarily affect not only the exchange rate between this pair, but all other exchange rates as well. Consequently, intervention to move one exchange rate in a desirable direction of to calm fluctuations in that exchange rate may cause another exchange rate to move in an undesirable direction or to become more volatile.
} 
exchange rate or in interest rates will be necessary to motivate investors to hold this portfolio. In summary, when two domestic money supplies have been unaffected by an intervention activity, the intervention can have a permanent impact on the exchange rate only if foreign and domestic securities are imperfect substitutes.

\section{INTERVENTION AND DOMESTIC MONETARY POLICY}

The foregoing discussion has emphasized that the relationship between domestic monetary policy and intervention depends on whether the intervention is sterilized. Domestic monetary policy cannot be conducted independently of unsterilized intervention since, as discussed above, it is tantamount to conducting monetary policy through foretgn exchange market operations. Thus, the exchange rate is a third alternalive monetary target variable to those more frequently considered - namely, monetary aggregates or interest rates.

Because there can be only one monetary policy stance, the role of unsterilized intervention depends crucially on the importance that policymakers place on the exchange rate as an objective for monetary policy. In particular, the use of unsterilized intervention necessarily implies that the monetary authority places relatively more importance on reducing the risks and real economic disturbances associated with exchange rate movements than achieving domestic targets for inflation and unemployment. The manipulation of monetary policy to achieve exchange rate objectives inevitably will conflict - occasionally or frequently - with the policy stance required to achieve these domestic objectives.

Furthermore, exchange rate movements may be motivated not only by changes in the desire to hold domestic currency (which probably should be offset by changes in the domestic money supplyl, but also by a host of other factors, especially the policies followed by foreign policymakers. Directing domestic monetary policy at an exchange rate farget, then, subjects the domestic economy to disturbances from both domestic and foreign sources. Consequently, the monetary authority loses its ability to control its own money supply independently of foreign events

The desire to influence exchange rate movements without losing control of the domestic money supply is the primary motivation for using sterilized intervention. Whether a monetary authority can separate ex- change rate management from money stock control, however, depends on whether certain conditions are met. First, international assets (including currencies) must be imperfect substitutes. Second, the magnitude of sterilized intervention undertaken must be large enough - given the degree of imperfect substitutability - that market participants cannot undo this effect by engaging in offsetting transactions.

\section{SOME EVIDENCE ON THE EFFECTIVENESS OF INTERVENTION}

Assessing the efficacy of intervention is difficult because data on central bank intervention are not made available; in contrast to domestic central bank transactions, which are reported in great detail, international transactions are reported only in a non-systematic, summary form. Three pieces of qualitative evidence, however, can be used to gauge the likely effectiveness of intervention. The first is an indirect assessment obtained by considering a domestic policy experiment; somewhat analogous to sterilized intervention, which occurred in the early 1960 s. The second is an assessment of the potential for the U.S. monetary authorities to influence the foreign exchange market by comparing the volume of assets and the rate of transactions in these markets by private investors with the monetary authority's holdings and activities. The third is a direct assessment of U.S. and other central bank intervention activity revealed in a working group study prepared for the 1983 Williamsburg Economic Summit Meeting.

\section{An Analogous Polley: Operation Twist}

A historical example of a domestic policy experiment by the federal Reserve that is similar to sterilized intervention is "Operation Twist." During 1961-62, the Federal Reserve sold short-term U,S. securities and used the proceeds to buy long-term U.S. securities; as with sterilized intervention, the transactions were offsetting so that the money supply was unchanged. The resulting increase in short-term government securities and the concomitant decline in long-term government securities in private portfolios were intended to raise the yield on short-term securities and lower the yield on long-term securities, thus " twisting" the term structure. ${ }^{12}$

In this effort, the first condition discussed above was met - namely, long-term securities bear higher interest rates than short-term securities, and, thus, the

\footnotetext{
${ }^{12}$ See Malkiel (1966), pp. 219-43.
} 


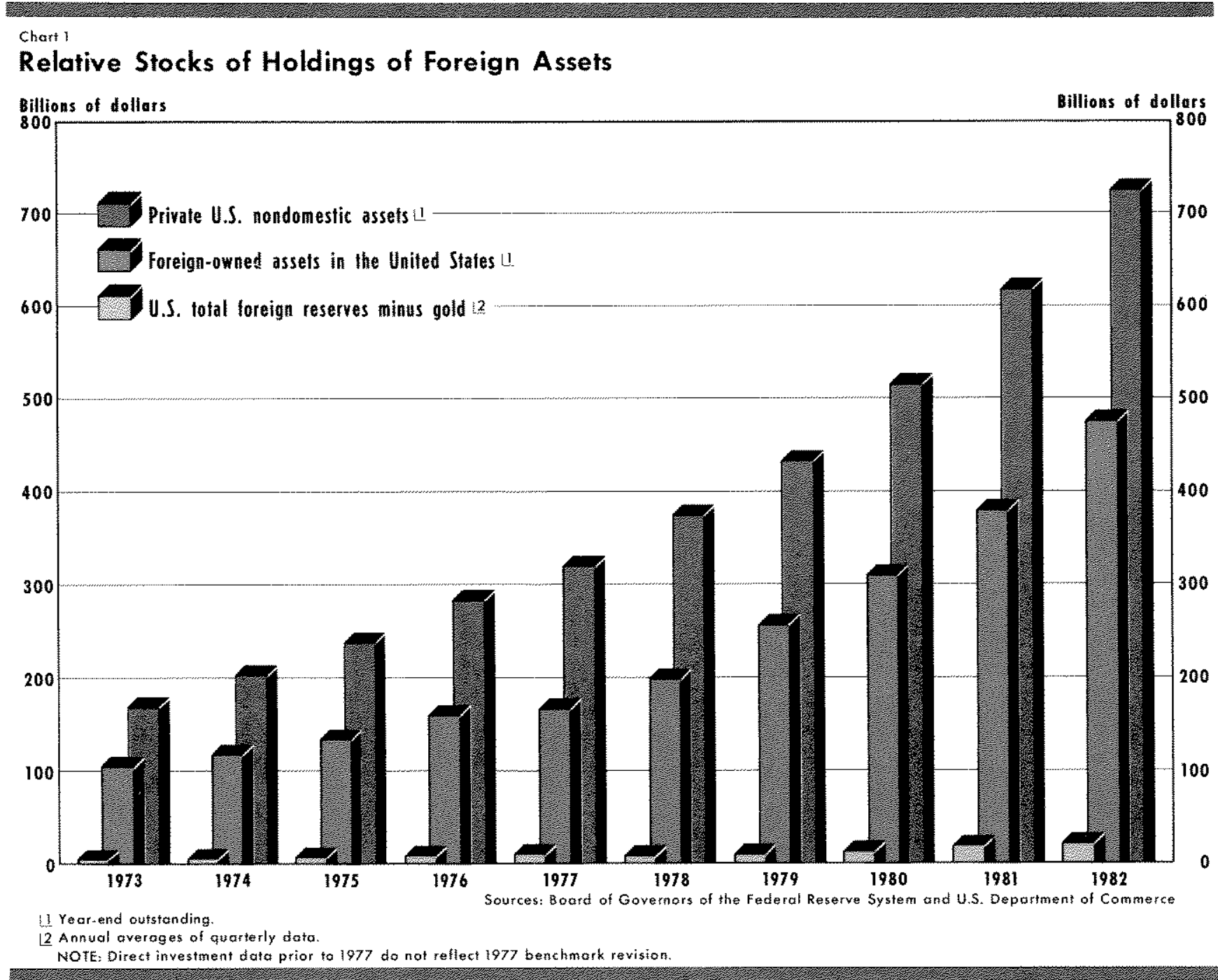

two assets are imperfect substitutes. Yet, the effort is generally judged to have failed primarily because the policy was not executed vigorously enough. ${ }^{13}$ The point (as emphasized by Malkiel) is that a central bank policy of affecting the term structure for interest rates depends, for its effectiveness, on two points: the bank's ability to affect significantly the relative supplies of short- and long-term financial assets and its willingness to do so. In this case of intervention in domestic asset markets, the extent of the activity was inadequate to have any significant impact.

Similarly, when sterilized intervention in foreign exchange markets is undertaken, the immediate distribu-

${ }^{13}$ As Johnson (1963), cited in Malkiel, p. 234, concludes:

Whatever might have beer expected of this policy... it was not in fact pursued in any effective sense. As a result primarily of Treasury funding operations, the maturity of the debt in the hands of the public has in fact been lengthened appreciably, instead of shortened as the policy would require. tion of currencies and securities denominated in those currencies is altered; two market activities, however, are thereby set in motion that tend to undo any impact on relative interest rates and the exchange rate. First, private entities - banks, primarily, but also individual traders - sell or buy securities denominated in the currencies that have been affected. Second, actual currency flows and options to buy or sell currencies or forward contracts are changed. Thus, unless the central bank is prepared to take sufficient actions to alter market expectations, it will be unlikely to affect the exchange rates by sterilized intervention.

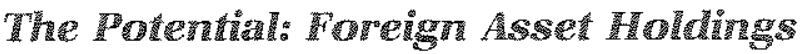 and the Sire of the U.S. Forergh

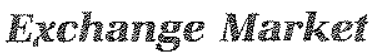

The likelihood that intervention can affect exchange rates may be assessed by comparing either private and 
Chat 2

\section{Relative Investment Flows into Foreign Assets}

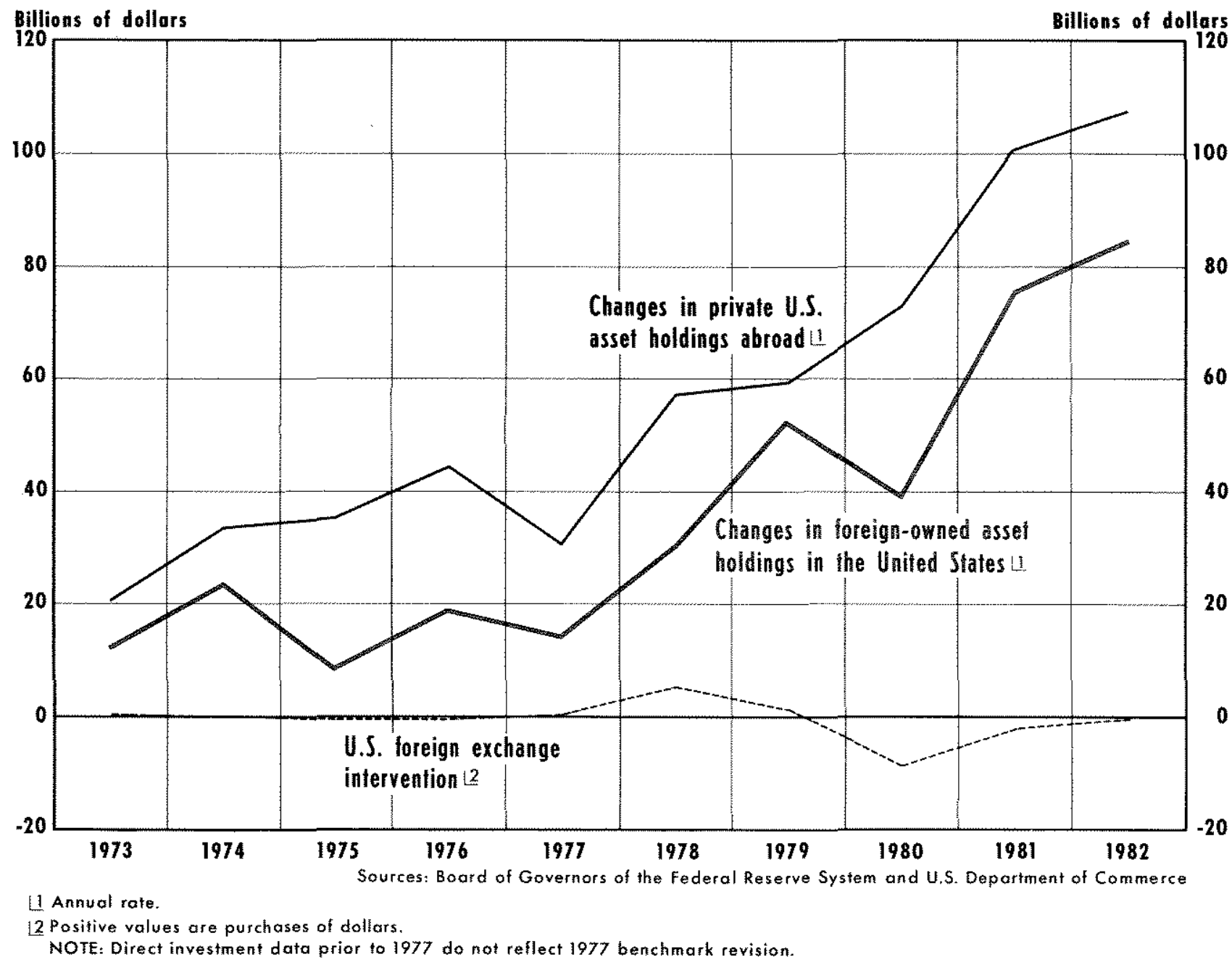

central bank foreign asset holdings or central bank activity and the size of markets for foreign exchange. The relevance of foreign asset holdings is that changing any single exchange rate changes the price of these assets in two or more currencies. Consequently, exchange rate movements caused by intervention may be presumed to induce shifts in desired portfolios of assets - that is, flows of asset sales and purchases that tend to offset such changes.

Chart 1 shows the stocks of foreign assets held by U.S. individuals and institutions, U.S. assets held by private foreigners, and the foreign reserves (minus gold) of the U.S. Federal Reserve System and the Trea* sury. It is clear that private investors hold a much largef share of assets traded in international markets than do the Fed and the U.S. Treasury. Consequently, to change the price at which these assets are valued would require very aggressive intervention.

Many have argued that the primary impact of intervention is on the flow demands for the currencies involved. If so, one should compare the flows of transactions in these markets Father than asset holdings. ${ }^{14}$ From this perspective, consider chart 2 - transactions in international markets. Comparing the rate of ac-

\footnotetext{
${ }^{14}$ This leaves aside, for the moment, the indirect effect of intervention through changes in expectations of future central bank policy, which will be considered later.
} 


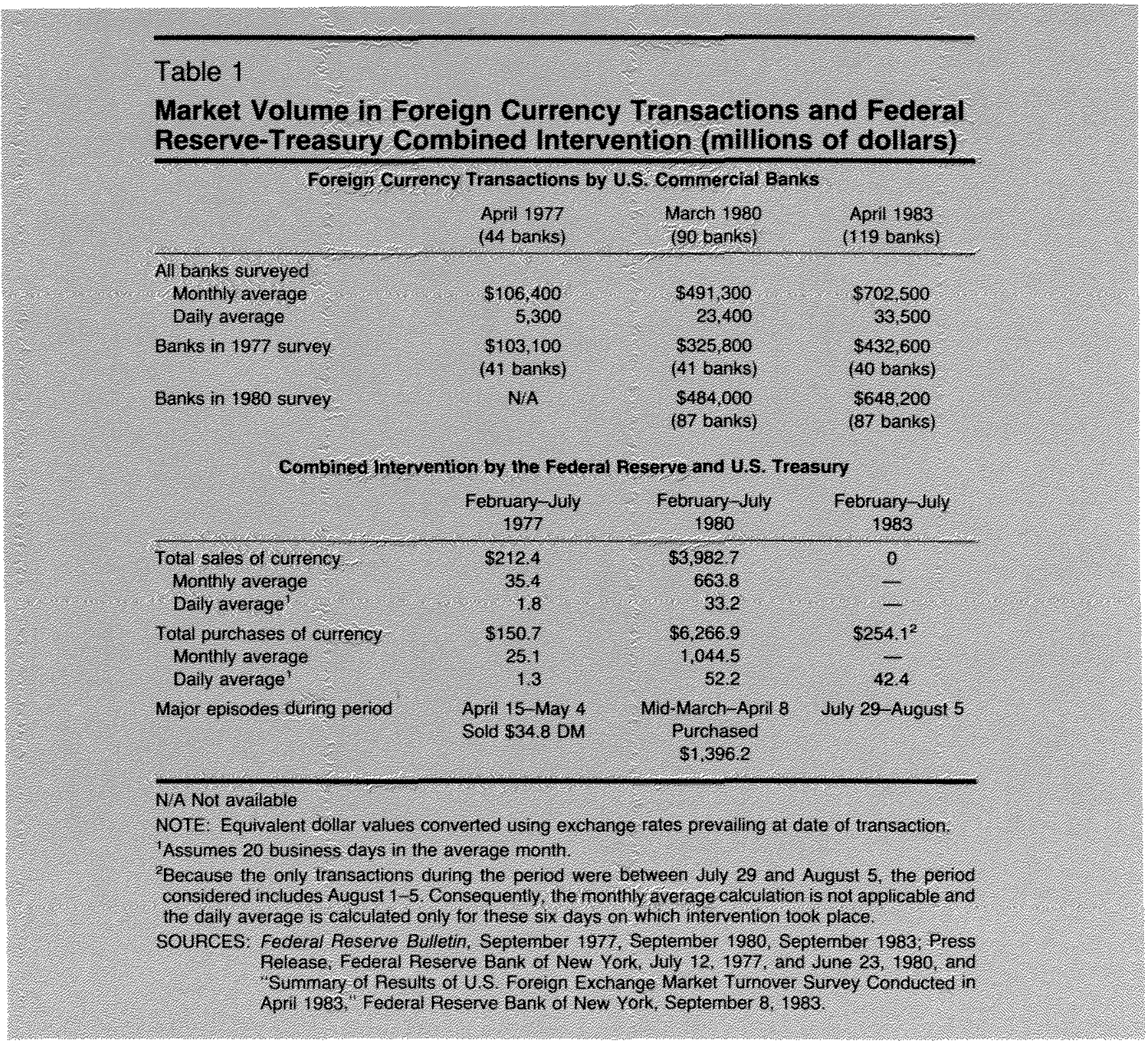

quisition of foreign assets by U.S. investors with the rate of intervention by U.S. monetary authorities (combined U.S. Treasury and Federal Reservel clearly demonstrates that the private U.S. investment activity on an annual basis swamps that of the authorities, and, in fact, so has the rate of purchase of U.S. assets by foreigners in recent years.

Another, perhaps even more relevant, comparison would be the transaction rates over intervals shorter than a year. That is, it might be argued that chart 2 shows net figures over an irrelevantly long time period: what matters is the gross volume of transactions in, say, a month or a day. From this perspective, consider the data in table 1, which reports the turnover statistics for U.S. banks engaging in significant volumes of foreign currency transactions. ${ }^{15}$ As the table shows, both the volume (in the observed month) per bank and the number of banks with significant involvement in foreign currency markets have risen dramatically since 1977. The total volume has risen sevenfold, comprising a quadrupling in the per-bank volume (indicated by the changes in the activity of the banks originally surveyed in 1977 ) and a tripling (from 44 to 119) of the number of banks actively participating in foreign cur-

\footnotetext{
${ }^{15}$ The data in the first half of table 1 are from periodic surveys of U.S. banks that engage in significant foreign exchange market transactions. These surveys are conducted by the Federal Reserve Bank of New York. For more detalls about these surveys, see Revey (1981).
} 
rency markets. If the volume in contracts during Aprit 1983 is expressed in a daily average form, the market in U.S. banks alone is about $\$ 33.5$ billion. Almost twothirds of these confracts are spot currency exchanges.

In comparison, the table also reports the combined Federal Reserve-U.S. Treasury intervention for the full six-month period containing each of the three survey dates along with representative episodes of significant US. intervention. As even a cursory review of the data reveals, U.S. intervention activity has been trivial relative to the volume of bank trading in currencies; only rarely has intervention been more than a tiny fraction of the private market volume. Consequently, the notion that the central bank has influenced the market price of currencies - their exchange rate - purely by affecting the flow volume of exchange is inconsistent with the recent record.

\section{Some Direct Evidence: Report of the Working Group on Exchange Market Intervention}

Central bank intervention - whether in domestic asset markets or international currency markets - can be effective only if the market is convinced that the monetary authority is both able and willing to affect the flows of transactions. In view of the growing size of private currency markets and the conflict with domestic inflation policies that effective intervention would require, such an effect on market expectations also seems to be beyond the grasp of the U.S. authorities.

Support for this conclusion is provided by the study of exchange market intervention conducted by the working group established at the Versailles Summit in 1982. ${ }^{16}$ This report is especially significant since it represents the most comprehensive analysis of the motives, methods and impacts of central bank intervention in foreign exchange markets that has been conducted using actual intervention data - data unavatable to most researchers.

While the working group found that sterilized invervention is not totally ineffective, its effect was much smaller than that of unsterilized intervention, ${ }^{17}$ Fusthermore, the group found that intervention could be effective in the face of persistent market pressures only if it was supported by complementary changes in

\footnotetext{
${ }^{16}$ Report of the Working Group on Exchange Market Intervention (1983). What follows is a synopsis of the major concusions drawn in this report.

${ }^{17}$ Additional support, af least for Germany, is provided by Obstreld (1983), pp. 184- 85 , as he concludes that:
}

domestic policy, especially monetary policy. When inconsistencies have arisen between domestic policy and exchange rate objectives, the group found that intervention (counter to the goals of domestic policy) was frequently useless and even counterproductive in the absence of supportive domestic policy. Consequently, the ministers, in their statement released with the working group's report, downplayed the importance of sterilized intervention as a separate policy tool:

We have reached agreement that, under the present circumstances, the role of [sterilized] intervention can only be limited.... Intervention will normally be useful only when complementing and supporting other policies. ${ }^{18}$

\section{CONCLUSION}

Most discussions of the effectiveness of central bank intervention focus on expectations of market participants and how intervention alters them. Yet, even if the central bank is capable of altering market expectations about its future policies, such a change can be brought about only if the market is convinced that other policy goals - the domestic inflation rate, level of interest rates, stability of domestic credit markets, etc. - аге subordinate to exchange rate manipulation. For the United States, at least, such a policy stance would not be credible. Thus, the efficacy of exchange Fate intervention would seem to be diminished greatly by the public's knowledge of the primacy of other monetary policy objectives. ${ }^{19}$

The model's verdict was that the Bundesbank has little if any power to intuence the exchange rate over that time span [one month] without altering current or expected future money-market conditions lie. without conducting unsterilized intervention].

${ }^{18}$ Statement on the Report of the Working Group on Exchange Market intervention (1963), p. 2.

${ }^{19}$ Consider agan the view of former Bundesbank President Em minger (Bank for Intemational Settlements [1982], pp. 5-6):

To sum up: Exchange rate policies cover a wide spectrum: from simply having a view' on the exchange rate to smoothing out disordery conditions' to avoiding excesses which are palpably faf out of line with fundamentals and are disturbing. The instruments range from intervertion to interest rate policy, genera monetary and other economic policies, and to offeial borlowing or lending.

There is also a wide spectrum in the use of such policies from country to country. This is partly a question of size. For the United States, there ts quite certaitly no other soution but free floating. The problems of a more active exchange rate policy are mainly relevant for middle-sized industrial courtries. It ts therefore natural and understandable that the atitude lowards exchange rate policy differs between the United States and other industrial countries.

There is also another important difference, which makes the United States a special case. Other industrial countries usually take the dolar as yartstick and intervene against the dollar. For the United States, it is more diticult to decide against which indiduidual currencies they should measure the walte of their currency, and against which to intervene in case of need. This is one of the several problems or which the oftrequested joint and concerted intervention policy would founder. 


\section{FERERECES}

Arenson, Karen W. "Dollar Seen at or Near Peak," New York Times, February 14, 1984.

Balbach, Anato: B. "The Mechanics of Intervention in Exchange Markets," this Review (February 1978), pp. 2-7.

Bank for International Settlements. Press Review (February 18, 1982). pp. $2-6$.

Bank for Intemational Settlements. Press Review (February 7 , 1984), pp. $1-5$.

Batten, Dallas S., and Mack Ott "Five Common Myths About Floating Exchange Rates," this Review (November 1983), pp. 5-15.

Bergstrand, Jeffrey $H$. "Is Exchange Rate Volatility 'Excessive"?" New England Economic Review (September/October 1983), pp. 5-14.

Feldstein, Martin. "The Worid Economy Today," The Economist (June 11, 1983), pp. 43-48.
Johnson, Harry G. "An Overview of Price Levels, Employment, and the Balance of Payments, "The Joumal of Business (July 1963), pp. $279-89$.

Kraus, Albert L. "Turn in Dollar's Value Already May Be at Hand," New York Journal of Commerce, February $14,1984$.

Kubarych, Roger M. Foreign Exchange Markets in the United revised edition (Federal Reserve Bank of New York, 1983).

Malkiel, Burton Gordon. The Term Structure of interest Rates (Princeton University Press, 1966).

Obstfeld, Maurice. "Exchange Rates, Inflation, and the Sterilization Problem: Germany, 1975-1981," European Economic Review (March/April 1983), pp. 161-89.

Report of the Working Group on Exchange Market Intervention established at the Versailles Summit of the Heads of State and Government, June 4, 5, and 6, 1982 (March 1983).

Revey, Patricia A. "Evolution and Growth of the United States Foreign Exchange Market," Federal Reserve Bank of New York Quarterfy Review (Autumn 1981), pp. 32-44. 